\title{
Estereotipos de género en publicidades de productos orientados al público infantil en Argentina*
}

\author{
Gender stereotypes in products advertising targeted to children in \\ Argentina
}

Estereótipos de género em publicidades de produtos orientados ao público infantil na Argentina

Recibido el 11 de diciembre de 2015. Aceptado el 19 de marzo de 2016

\author{
Andrea Natalia Melo** \\ Argentina \\ Julieta Astorino*** \\ Argentina
}

- Para citar este artículo:

Melo, Andrea Natalia y

Astorino, Julieta (junio, 2016).

Estereotipos de género en

publicidades de productos

orientados al público infantil en

Argentina. Ánfora, 23(40), 17 -

50. Universidad Autónoma de

Manizales. ISSN 0121-6538.

\section{Resumen}

Objetivo: caracterizar la construcción, reproducción y re-elaboración de estereotipos de género presentes en las publicidades audiovisuales y gráficas, transmitidas en Argentina en el período 2011- 2014, referidas a productos de consumo infantil, en tanto expresión de violencia simbólica hacia las mujeres, de acuerdo con la

\footnotetext{
* Artículo derivado del proyecto: "Violencia simbólica en el ámbito mediático: estereotipos de género en las publicidades de productos para consumo infantil. Un análisis cualitativo de publicidades transmitidas en Argentina durante el período 2004-2014". Este trabajo fue desarrollado en el marco de un curso regular ("Aportes de la teoría de género al análisis de lo social") de la carrera de Sociología de la Universidad de Buenos Aires, Argentina. Tuvo comienzo en el mes de agosto de 2014 y finalizó en noviembre del mismo año. Recibió el apoyo institucional de la cátedra que dictaba el curso.

** Licenciada en Sociología de la Universidad de Buenos Aires, Argentina. Docente en escuelas secundarias públicas y privadas de la provincia de Buenos Aires, Argentina. Correo electrónico: meloandreanatalia@ gmail.com

*** Estudiante avanzada de la Licenciatura en Sociología, Facultad de Ciencias Sociales, Universidad de Buenos Aires, Argentina. Investigadora estudiante de la Facultad de Ciencias Sociales, UBA. Correo electrónico: astorinojuli@gmail.com
} 
definición establecida por la Ley 26485. Metodología: mediante la técnica del análisis documental, en el marco de una metodología cualitativa, se procedió a relevar, describir y analizar las publicidades seleccionadas, haciendo uso de los buscadores de Google, Facebook y Youtube, a partir de un muestro intencional. En una primera instancia se realizó una descripción y análisis de cada publicidad en particular con el fin de identificar los estereotipos de género presentes, a partir de dos categorías o tópicos (mandatos sociales diferenciados por género y el rol de mujer madre cuidadora). Luego, se desarrolló un análisis externo, procurando describir y analizar cada publicidad inserta en el conjunto de circunstancias sociales y culturales que las sustentan, buscando dar cuenta de los procesos socio-culturales que las legitiman y sostienen. Resultados: se evidenció que las publicidades de productos infantiles constituyen una instancia más de violencia simbólica hacia las mujeres, ya que se perpetúan una serie de modelos de "ser mujer" asociados a los quehaceres domésticos/privados, a la sumisión, a los roles pasivos en la sociedad, entre otros, y en oposición a modelos de "ser varón" anclados a roles activos, de fuerza, superioridad, actividades públicas, etc. Conclusiones: considerando a la violencia en términos relacionales e inscripta en relaciones sociales de poder, se afirma que la violencia de género opera sosteniendo una estructura social desigual de dominación hacia las mujeres.

Palabras clave: Violencia Simbólica; Estereotipos de Género; Medios de Comunicación; Publicidad.

\section{Abstract}

Objective: to characterize the construction, reproduction and re-elaboration of gender stereotypes in audiovisual and print advertising seen in Argentina between 2011 and 2014. This advertising refered to products consumed by children as an expression of symbolic violence against women, according to the definition established by Law 26485. Methodology: a document analysis within a qualitative methodology approach was used. A convenience sampling from Google, Facebook and Youtube was studied to relieve, describe and analyze the chosen advertising. First, each audiovisual and print ad was described and analyzed to identify gender stereotypes based on two categories or topics: distinct social mandates by gender and the role of women caring mothers. Then, an external analysis consisted on describing and analyzing every ad within all social and cultural circumstances that support it was carried out. The analysis focused on knowing the socio-cultural processes that legitimize and sustain them. Results: it was evident that advertising of children's products is other way of symbolic violence against women. It perpetuates a series of models of "being a woman" which are associated with domestic and private chores, submission, passive roles in society, among others, 
in contrast to models of "being male" associated with active roles, strength, superiority and public activities, etc. Conclusions: the gender violence acts on holding an unequal social structure of domination towards women when it is understood as a relational concept and is attached to social power.

Keywords: Symbolic Violence, Gender Stereotypes, Media, Advertising.

\section{Resumo}

Objetivo: caracterizar a construção, reprodução e reelaboração de estereótipos de gênero nas publicidades audiovisuais e gráficas, transmitidas na Argentina entre 2011 a 2014, referidas a produtos de consumo infantil como expressão de violência simbólica em direção às mulheres, de acordo com a definição estabelecida pela Lei 26485. Metodologia: mediante a técnica da análise documental, no marco de uma metodologia qualitativa, procedeu-se a relevar, descrever e analisar as publicidades selecionadas, fazendo uso dos buscadores de Google, Facebook e Youtube, a partir de uma amostra intencional. Primeiro, realizou-se a descrição e análise de cada publicidade com o fim de identificar os estereótipos de género presentes, a partir de duas categorias ou tópicos (mandatos sociais diferenciados por género e o rol de mulher mãe cuidadora). Logo, desenvolveu-se uma análise externa, procurando descrever e analisar cada publicidade inserta no conjunto de circunstancias sociais e culturais que as sustentam, buscando dar conta dos processos socioculturais que as legitimam e sustentam. Resultados: evidenciou-se que as publicidades de produtos infantis constituem uma instancia mais de violência simbólica em direção às mulheres, já que perpetuam uma série de modelos de "ser mulher" associados aos afazeres domésticos/ privados, à submissão, aos roles passivos na sociedade, entre outros, e em oposição a modelos de "ser varão" ancorados a roles ativos, de força, superioridade, atividades públicas, etc. Conclusões: considerando a violência em termos relacionais e subscrita em relações sociais de poder, a violência de género opera sustentando uma estrutura social desigual de dominação em direção às mulheres.

Palavras-chave: Violência Simbólica; Estereótipos de Género; Meios de Comunicação; Publicidade. 


\section{Introducción}

Desde las ciencias sociales se pueden concebir los géneros como construcciones histórico-culturales, que proporcionan características y significados específicos de lo masculino y lo femenino. Las nociones de masculinidad y feminidad se fijan en un conjunto de representaciones y prácticas producto de paradigmas dominantes, profundamente aferrados en la cultura; forman parte de un campo complejo de interacciones y representaciones de diversos tipos (sexual, estético, ético, afectivo, etc.), a partir de los cuales se desprenden ciertos roles, comportamientos, actitudes corporales, expectativas y modos de sensibilidad y conocimiento según los ámbitos de la vida cotidiana. En otras palabras, "la dimensión de género es estructurante y constituyente del sujeto y de las relaciones sociales" (DGCyE: 2010, p. 80).

Desde la perspectiva de Scott (1990), "el género es un elemento constitutivo de las relaciones sociales basadas en las diferencias que distinguen los sexos y es una forma primaria de relaciones significantes de poder" (p. 46). Siguiendo su definición, el género comprende cuatro elementos: símbolos culturales que evocan representaciones, conceptos normativos, nociones políticas y la construcción de subjetividades. Es aquí donde se puede ubicar la acción de los medios de comunicación, pues éstos suelen contribuir a la producción y reproducción de los elementos mencionados y, por ende, de roles y estereotipos de género, de formas hegemónicas de construcción social de los cuerpos.

$\mathrm{Al}$ respecto, Bourdieu (2000) advierte que el modo en que se ha repartido el mundo de manera dual, pone a las mujeres en una situación de invisibilización, desigualdad y desvalorización en un orden social regido por el principio universalizador de lo masculino, también conocido como modelo de dominación patriarcal. De allí que la visión dominante de la masculinidad atraviesa las formas en que se interpretan los cuerpos, las relaciones (entendidas como relaciones de poder) y se amplía a todos y cada uno de los campos de lo social: el trabajo, la familia, la escuela, la comunicación (DGCyE, 2010).

De acuerdo con lo afirmado, y con el propósito de visibilizar el papel que desempeñan los medios de comunicación en la reproducción de pautas culturales asociadas a los roles y estereotipos de género, se desarrolló una investigación de carácter exploratoria, de la que se deriva este estudio preliminar que pone especial atención en la publicidad, concibiéndola como un instrumento eficaz para la cristalización y naturalización de la desigualdad de género, de la división sexual del trabajo (para su inmediata reproducción) y, por tanto, de la violencia 
simbólica ${ }^{4}$ que se ejerce desde el ámbito mediático, al difundirse a través de los medios.

Particularmente, este estudio se focalizó en la publicidad referida a productos de consumo infantil, por varios motivos. Primero, porque se entiende que desde la niñez tales productos comienzan a modelar y construir representaciones sobre los cuerpos y estereotipos de género, que se interpretan como formadores y constructores de prácticas diferenciadas por género desde temprana edad. Funcionan como un actor más entre otras instituciones (familia y escuela, por ejemplo) que inciden en la socialización primaria de niños y niñas. Estas incidencias dejan las primeras marcas en las y los sujetos, que delimitan y diferencian fuertemente los roles de género, pasando a formar parte de mandatos a seguir para ser aceptable socialmente, estableciendo ciertos parámetros de "normalidad". A su vez, porque se cree que reproducen o construyen ciertos modelos de división sexual del trabajo al interior de los hogares (mamá cuidadora, cocinera, papá ausente, papá trabajando, entre otros), reforzando la desigualdad entre varones y mujeres.

Y segundo, y no menos importante, por la escasez o falta de estudios/ trabajos académicos en el país que indaguen sobre publicidad sexista infantil, constituyendo de esta manera, por así decirlo, un "área de vacancia"

En este artículo se visibiliza la construcción de roles y estereotipos de género presentes en las publicidades referidas a productos de consumo infantil, a partir de un análisis y descripción de las mismas, guiadas por una serie de interrogantes o preguntas de investigación como las siguientes: ¿Qué juegos/juguetes suelen asociarse a los niños y niños?, ¿Con qué actitud/rol suele representarse a mujeres-varones y niñas-niños?, ¿Qué lugar ocupan varones y mujeres cuando se los representa en el hogar?, ¿Las publicidades presentan situaciones que salen de lo convencional, de la heteronorma? ¿QQué modelos alternativos o novedades deberían incorporarse en la pauta publicitaria?, ¿Es posible una nueva forma de comunicar y publicitar, más inclusiva y menos sexista?

\footnotetext{
4. Deacuerdoconla Leyn²6.485 de 2009 laviolenciasimbólicaes laqueatravés depatronesestereotipados, mensajes, valores, íconos o signos transmita y reproduzca dominación, desigualdad y discriminación en las relaciones sociales, naturalizando la subordinación de la mujer en la sociedad.

5. La mayoría de las iniciativas o escritos sobre el tema son de tipo periodístico o de la gestión pública gubernamental, como por ejemplo: http://www.rosario.gov.ar/sitio/desarrollo_social/mujer2/juego5.jsp. Los trabajos de tipo académico sobre este aspecto son escasos, o no tienen la difusión que permita acceder a los mismos, de acuerdo con lo que se indagó. Sí los hay sobre publicidad sexista en general, estereotipos de género, violencia. Las investigaciones referidas al tema que se han consultado, son en su mayoría, de España, Estados Unidos, Inglaterra.
} 
De esta manera, se buscará advertir el mecanismo por el cual las publicidades audiovisuales seleccionadas, que fueron transmitidas en Argentina en el período 2011-2014, referidas a productos de consumo infantil refuerzan, re-construyen y reproducen estereotipos de género como expresión de violencia simbólica hacia las mujeres. Se indagará si las publicidades seleccionadas refuerzan estereotipos de género no sólo en relación con el público infantil al que está dirigido, sino también respecto al público adulto al que interpelan (madre y padre).

Además, se buscará dar cuenta de las representaciones sociales de género más usuales construidas y reproducidas en dichas publicidades, pensando en las formas en que se cristalizan y los posibles modos de subvertirlas. En Argentina, a pesar de la existencia de un marco legal que sirve de respaldo, los mensajes difundidos por los medios de comunicación no suelen ofrecer una imagen equilibrada de hombres y mujeres tal como la Ley 26.522 del año 2009, sobre Servicios de Comunicación Audiovisual propone (retomando postulados de la Ley 26.485 de 2009 de Protección Integral para prevenir, sancionar y erradicar la violencia contra las mujeres en los ámbitos en los que desarrollen sus relaciones interpersonales $\left.{ }^{6}\right)$.

Es decir que, a pesar de la existencia de una importante herramienta legal que obliga a respetar la imagen de la mujer en los medios de comunicación, esta es constantemente ignorada por dicha industria. Ello se debe a que suele ser difícil llevar a la práctica la defensa jurídica de estos derechos, ya que el respeto por la libertad de expresión sólo permite que organismos del Estado abocados a la tarea, "sugieran" comportamientos más igualitarios a los realizadores de anuncios, con lo cual la capacitación y colaboración de estos actores es central.

En lo que refiere a las publicidades sexistas (también de discriminación en general) y su control o regulación, existe el Observatorio de la Discriminación en Radio y Televisión, que las identifica, analiza y aplica las correspondientes "sanciones". Sin embargo, se observa la falta de estudios, comentarios o regulaciones de parte del ente en lo referido a publicidades sobre productos destinados al público infantil, constituyendo nuevamente un "área de vacancia" en términos académicos y socio-políticos. Y en tanto posibilidad de generar nuevas formas alternativas y más igualitarias de comunicar y publicitar.

6. Observatorio de la discriminación en radio y televisión (2014) Publicidades sexistas y buenas prácticas. Extraído de http://www.obserdiscriminacion.gob.ar/?p=2584\#more-2584 


\section{Metodología}

La metodología es de tipo cualitativa. Se aplicó la técnica del análisis documental, que permite contribuir multidimensionalmente a la comprensión de la problemática en cuestión y recurre a las dimensiones socioculturales que le dan sentido y sustento a los discursos publicitarios circulantes.

El universo de estudio lo integran las publicidades gráficas y audiovisuales de productos orientados al público infantil (sean juguetes, pañales, medicamentos, comestibles, etc.) transmitidas en Argentina, entre los años 2011 y 2014. Se tomó como inicio del relevamiento el año 2011, tomando un período de (aproximadamente) dos años desde la sanción de la Ley n ${ }^{\circ} 26.485^{7}$, considerándolo un tiempo prudencial para que tanto publicitarios como empresarios, "adecuen" sus anuncios publicitarios al "espíritu" de la ley (específicamente, respecto a la violencia simbólica en el ámbito mediático).

El relevamiento se realizó a través de Internet, usando como herramienta principal YouTube, el buscador de imágenes de Google y las páginas de Facebook de algunas de las marcas de los productos escogidos. Se relevaron decenas de publicidades referidas a juguetes, alimentos, productos de higiene, cuidado, entre otros. También se realizó un muestro intencional ${ }^{\circledR}$, escogiendo aquellas publicidades que resultaron más ilustrativas y ejemplificadoras para la problemática de estudio, con base en la aparición (o no) de ciertas situaciones o casos (división sexual del trabajo, roles de género, estereotipos, entre otros). De esta manera, se analizaron 13 publicidades de las más significativas e ilustrativas.

Con los documentos insumo (publicidades) se procedió a realizar un análisis cualitativo de los mismos. En primera instancia se trabajó con cada una de las publicidades en particular, con el fin de identificar los estereotipos de género, construidos, re-elaborados y transmitidos. Para esto, se elaboraron dos tópicos o categorías de análisis que guiaron la actividad. Por un lado, la presencia de mandatos sociales diferenciados por género y por otra parte el rol de mujer madre cuidadora, entendiendo que estas categorías son imágenes recurrentes y reiterativas en las pautas publicitarias y en el discurso mediático en general. Así, se identificaron los modelos de ser mujer y ser varón que plantean a los niños

\footnotetext{
7. Ley de protección integral para prevenir, sancionar y erradicar la violencia contra las mujeres en los ámbitos en que desarrollen sus relaciones interpersonales. Sancionada: Marzo 11 de 2009. Promulgada de Hecho: Abril 1 de 2009.

8. Ver Capítulo 13, "Muestreo Cualitativo" en Hernández Sampieri, Roberto; Fernández Collado, Carlos; Baptista Lucio, Pilar (2007) Metodología de la Investigación (4ta Edición). México: Editorial Mc Graw Hill.
} 
y niñas a los que dirigen su producto y los modos de ser madre y ser padre que proponen a los adultos que interpelan (dado que la decisión de consumo del producto está en sus manos).

Luego, se procedió a interpretar y analizar las publicidades en el conjunto de circunstancias sociales y culturales que las sustentan, entendiendo que no son productos aislados de las sociedades en las que se despliegan y que no constituyen meras creaciones individuales escindidas de la historia y la cultura. Es decir, se complejizaron las relaciones entre las publicidades, entendiendo que cada una se encuentra en un hilo de relaciones y acuerdos de sentido respecto a ciertos aspectos de la cultura, en lo que refiere a los roles que varones y mujeres deben ocupar en una sociedad.

En otras palabras, el análisis está orientado a identificar, en clave de género (a partir de la definición de Scott ya mencionada) las formas de ser niña y niño que representan las publicidades, las actividades que cada uno de ellos se encuentran realizando en las mismas y los mandatos sociales planteados en el desarrollo de los anuncios publicitarios. Se buscó, además, dar cuenta de los modos en que se representa e interpela diferencialmente a madres y padres, involucrándolos de manera desigual en el cuidado y acompañamiento de sus hijos. Con esto se indagó cuáles son los roles y ámbitos en que se los suele colocar y de este modo, evidenciar que la violencia de género en el ámbito mediático es un problema político que, necesariamente, se debe desnaturalizar, si existe un interés en construir sociedades más igualitarias.

\section{Resultados}

A continuación se presentan los resultados orientados por las dos categorías conceptuales ya mencionadas: los mandatos sociales según género y el rol de mujer madre cuidadora. Las publicidades serán descriptas y analizadas desde estas categorías, pasando por aspectos de tipo comercial (producto, marca, descripción del anuncio) y de tipo contextual, en tanto producto de una cultura y sociedad determinada, que le imprimen determinadas características. 


\section{Roles, mandatos sociales y estereotipos a partir del análisis de las publicidades}

\section{Sorpresa diferenciada y mandatos sociales según género}

En términos generales, se puede afirmar que la publicidad infantil, más concretamente la referida a juguetes, reproduce roles y mandatos tradicionales según el género (salvo contadas excepciones), anunciando para las niñas: muñecas, juegos relativos al cuidado del hogar e hijos y tocantes al embellecimiento personal; para los niños, coches, juegos de aventuras, de acción y de construcción. Así, se produce una construcción y estereotipación de niños y niñas, asignándoles a los primeros roles activos en ámbitos públicos y a las niñas roles pasivos y en ambientes privados/domésticos.

Según lo anterior, se puede interpretar que los mensajes publicitarios, en general, repercuten no sólo en la venta de productos, sino que influyen también en el aprendizaje de comportamientos, actitudes y pautas de interacción social y, sobre todo, en los roles de género. Sin embargo, las publicidades para adultos suelen ser (generalmente) las más criticadas o más cuestionadas, descuidando, muchas veces, la incidencia y el impacto que también pueden generar las publicidades orientadas a niños y niñas (Pérez Ugena y Coromina, 2009).

Desde la temprana infancia, los medios han contribuido en la enseñanza acerca de que las mujeres deben ser "débiles, pasivas, asustadizas, sensibles, maternales, cuidadoras, dependientes, tiernas, emocionales, sentimentales. Los hombres, en cambio, deben ser fuertes, competitivos, seguros de sí, valientes, inquietos, independientes, activos, conquistadores y poderosos, racionales, proveedores, equilibrados, fríos, etc.” (Publicidades sexistas y buenas prácticas, Observatorio de la discriminación, 2014). Se considera que, de este modo, niños y niñas aprenden qué implica ser un varón y una mujer para la sociedad de la que forman parte, a partir de la oferta de juguetes diferenciados que reproducen estereotipos que determinan cómo deben ser (en este caso, a través del juego), sin admitir rasgos de otro tipo.

La primera publicidad que se analizará es la de huevos de chocolate "Kinder". La elección de dicha pauta se produjo a causa de que la compañía decidió lanzar a la venta (en el año 2013) los huevos de chocolate de siempre pero con envases diferenciados por género (rosa para niñas y celeste para niños, como se ve en la imagen $n^{\circ} 1$ ), advirtiendo desde el mismo "packaging" qué tipo de juguete 
tendrían adentro (si es celeste, un autito ${ }^{9}$ o un jugador de fútbol, si es rosa, algún obsequio enfocado "al gusto de las nenas", como muñecas, flores, entre otros) orientando así, a partir de estereotipos, el gusto de los consumidores-niñas/ niños en lo que concierne a su diversión.

Imagen 1. Envases Kinder Sorpresa (2013)

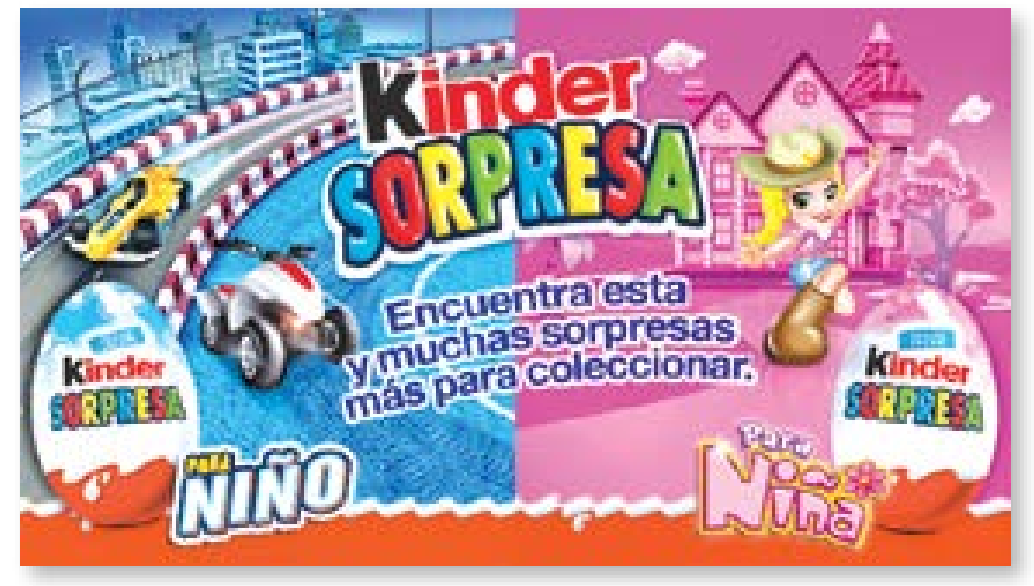

Fuente: Muhimu. Recuperado de http://muhimu.es/genero/mercadona/\#

Además, se ha decidido considerarla relevante teniendo en cuenta que ha sido objeto de debate público (en Argentina) durante el año 2013, en el momento en que la legisladora de la Ciudad de Buenos Aires y extitular del INADI, María José Lubertino, criticó los huevos "Kinder Sorpresa" señalando que el lanzamiento de obsequios diferenciados según el género de los niños "es un retroceso". Hasta entonces, el envoltorio era de color naranja, sin establecer distinciones genéricas.

Al respecto, la legisladora señaló que:

"la falta de igualdad de género es un tema serio que genera graves consecuencias y que comienza en pequeñas discriminaciones inadvertidas (...) Si desde pequeñas, las nenas pudieran jugar a la pelota o con autitos, habría más jugadoras de fútbol o corredoras de autos”. Si desde pequeños los nenes pudieran dar de comer a sus bebés de juguete, habría más padres cuidando a sus hijos (...) El tipo de juegos que se condicionan desde los primeros años de la infancia hacen de las nenas 
a veces madres cuidadoras y de los varones se busca desarrollar otro tipo de actitudes (Lubertino, 2013).

Las afirmaciones de la legisladora son de relevancia puesto que hacen hincapié en el modo en que las niñas y niños son influidos o condicionados (respecto de su forma de pensar, sentir, comportarse y relacionarse con el entorno) y cómo el aprendizaje suele darse sobre la base de modelos avalados y reproducidos por los medios de comunicación, entre otras instituciones (familia, escuela, iglesia, estado, etc.) que influyen en los jóvenes, en su proceso de formación y en la constitución de su propia identidad, a través de la construcción de un modelo binario y dicotómico de lo femenino y lo masculino (Publicidades sexistas y buenas prácticas, Observatorio de la discriminación, 2014)

A partir de 2014, la empresa lanzó un nuevo packaging, esta vez de color verde (imagen $\mathrm{n}^{\circ} \mathrm{Q}$ ) que tendría un regalo "neutro", y que puede estar dirigido tanto a varones como a nenas, como solía ser habitual en la marca.

Cabe problematizar como la publicidad orientada al público infantil incide en los procesos primarios de identificación humana, contribuyendo a una identificación, no en tanto persona humana sino como persona en tanto niña o niño, influyendo en la conformación de "identidades según género". Por otro lado, esta fuerza socializadora por género, desde temprana edad, dificulta los procesos de cambios necesarios para terminar contra la discriminación hacia las mujeres, dando lugar a lo que RadlPhillip (2014) considera la "doble dimensión de la violencia simbólica" a través de la permanente representación de estereotipos de género en la publicidad que contribuye a perpetuarlos dentro de la sociedad ${ }^{10}$.

Al respecto, numerosos informes internacionales han indagado sobre el tema. Es el caso, por ejemplo, de una investigación cuantitativa, en la cual se analizan publicidades sobre juguetes infantiles realizado por Pérez, Coromina y Martínez (2009) en el que se señalan algunos datos significativos que ya hemos mencionados; las muñecas y los accesorios son los juguetes más presentados a las niñas, mientras que los vehículos y figuras de acción y violencia son los más publicitados a los niños.

Así, resultan preponderantes los valores de belleza, maternidad, ámbito doméstico y seducción en la publicidad dirigida a niñas, perpetuando así el papel

10. Esto no quiere decir que no existan estereotipos de género discriminatorios o violentos hacia los varones, solo que no son objeto de indagación principal en este trabajo. 
tradicional de la mujer. Y por su parte, valores como la fuerza y poder están dirigidos claramente a los niños. Es así que, según señala el informe, a través de la publicidad relacionada con los juguetes, se siguen perpetuando los roles del pasado, provocando que las niñas pasen horas a la semana jugando a cuidar de un bebé, "haciendo tareas domésticas" o adorando a la muñeca "Barbie". Y que, por otro lado, "los niños empiecen a soñar ya con el mejor coche, que de adultos otro tipo de publicidad tratará de venderles y que jueguen con muñecos de acción que fomentan la normalización de la competitividad, la guerra y la violencia” (Pérez, Coromina y Martínez, 2009).

Imagen 2. Kinder Sorpresa con distinción de género (2013)

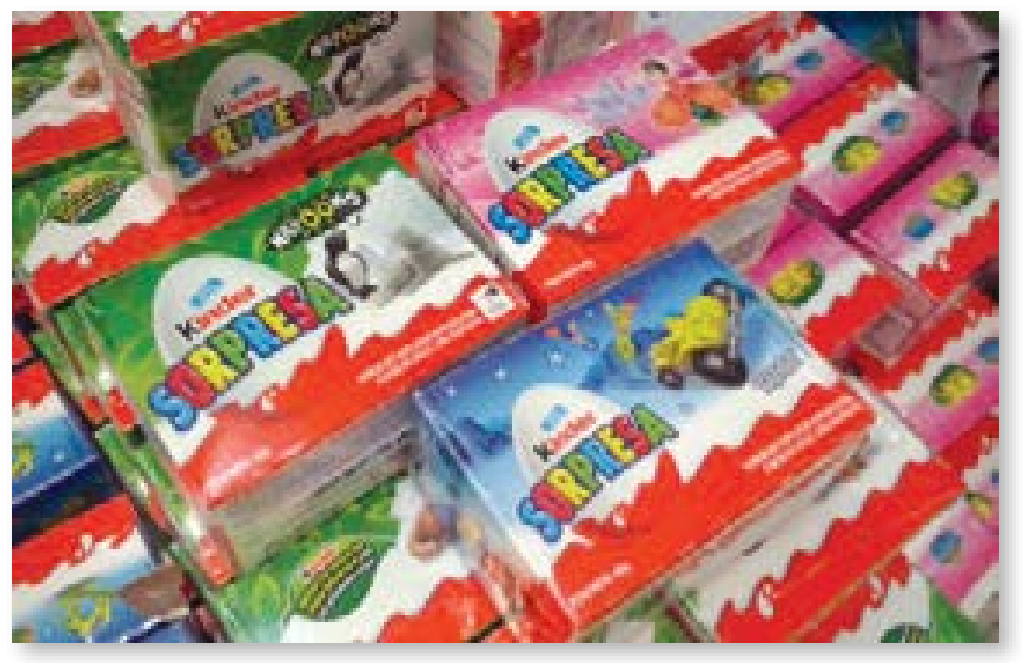

Fuente: Merca.2. Recuperado de http://www.merca20.com/huevos-kinder-celestepara-ninos-rosa-para-ninas-y-ahora-verdes/ 
Melo, Andrea Natalia y Astorino, Julieta (junio, 2016). Estereotipos de género en publicidades de productos orientados al público infantil en Argentina. Ánfora, 23(40), 17-50. Universidad Autónoma de Manizales. ISSN 0121-6538.

Imagen 3. Juguetes característicos para niños (2013)
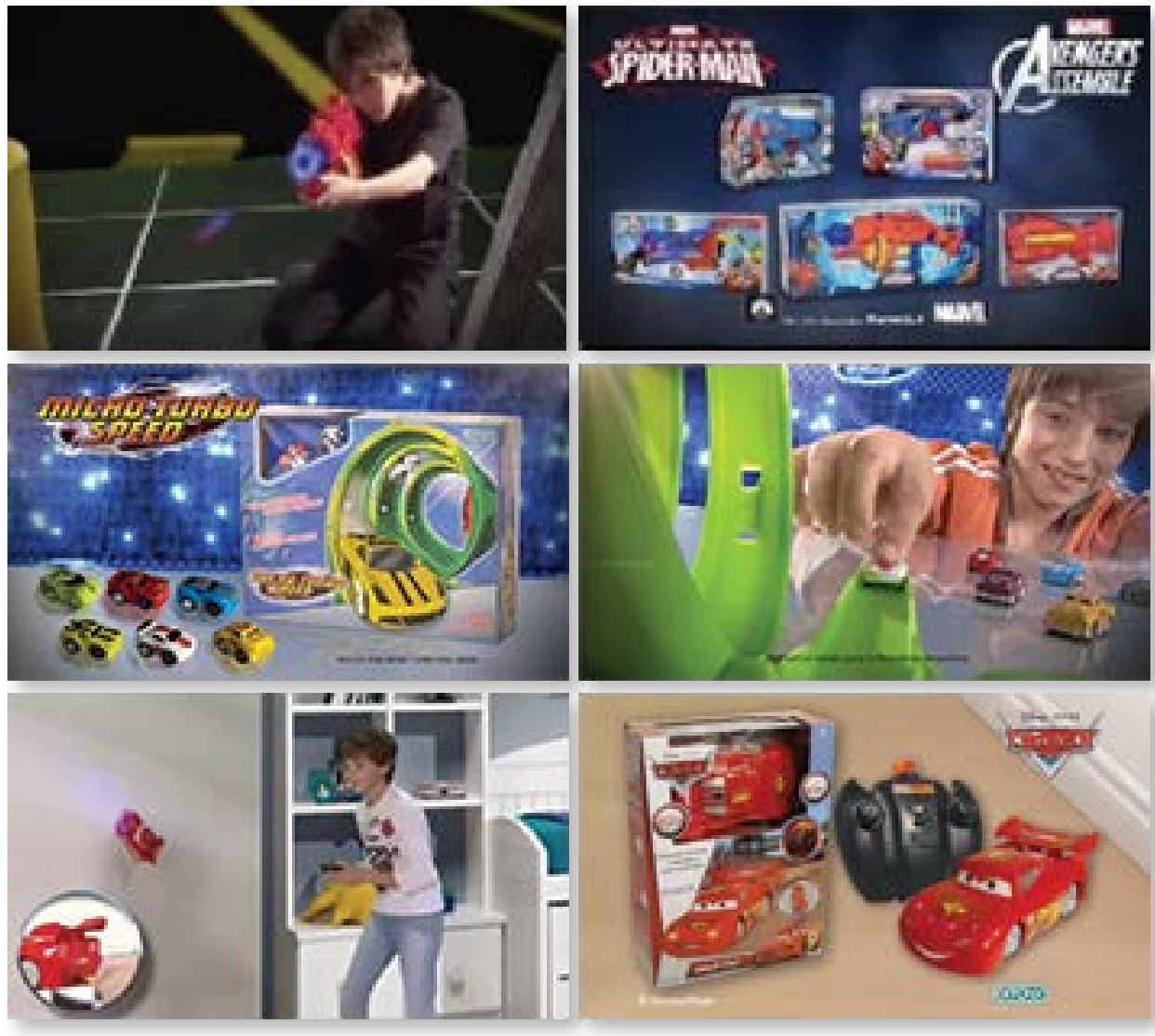

Fuente: Ditoys. Recuperado de http://www.ditoys.com.ar/videos.html

Ejemplos de lo mencionado pueden visualizarse en las publicidades televisadas en Argentina de la marca de juguetes "Ditoys", que si bien es de origen chino, publicita y comercializa sus productos en el país. Desde su página web ${ }^{11}$, es posible "buscar" juguetes diferenciados "para nenes" y "para nenas" y observar las publicidades de los mismos. 

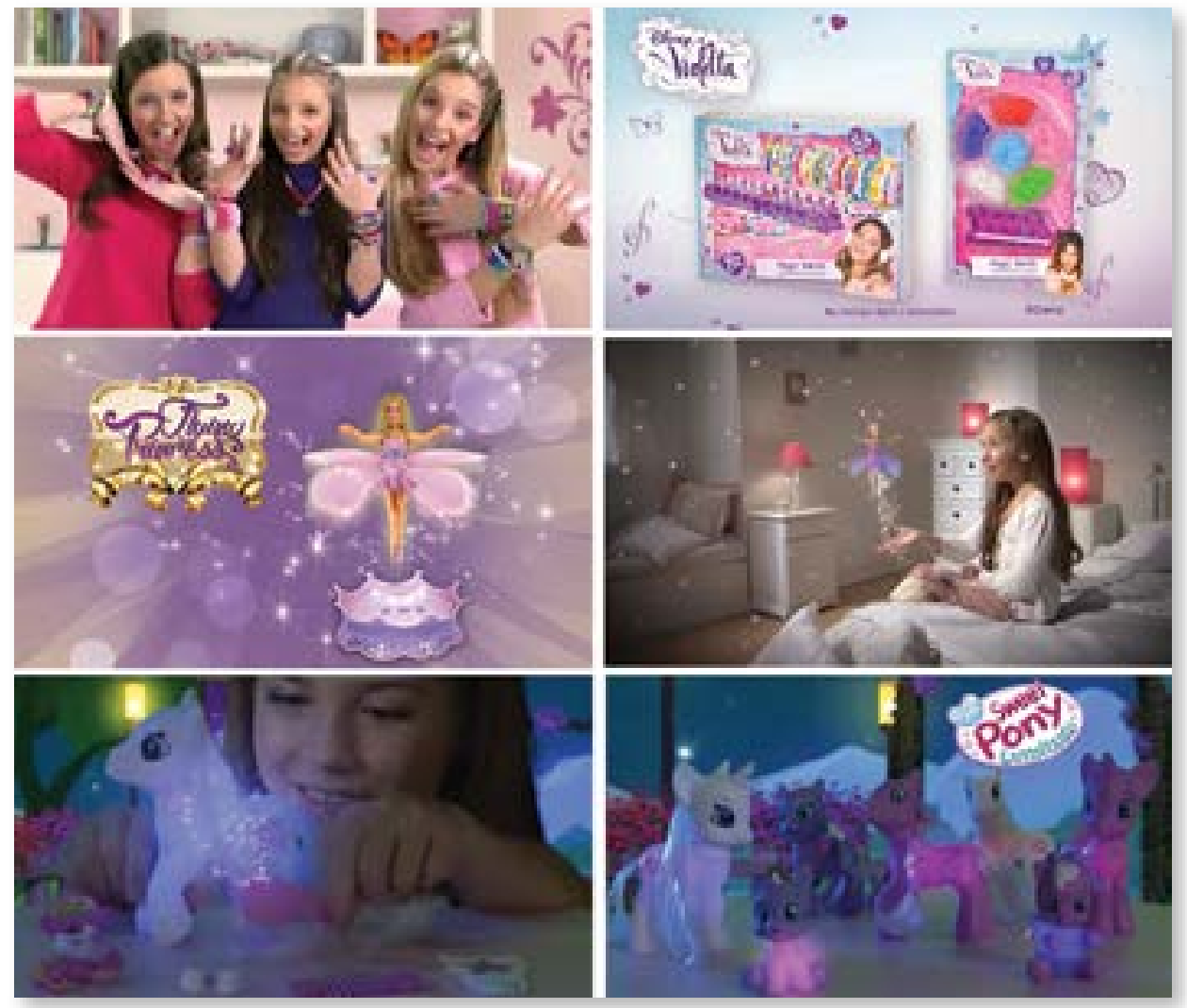

Fuente: Ditoys. Recuperado de http://www.ditoys.com.ar/videos.html

En los videos publicitarios que aparecen en el sitio web de la marca, los niños aparecen asociados con armas de juguetes y pistas de carrera, junto con autos a control remoto (imagen $n^{\circ} 3$ ). Por otro lado, a las niñas se les ofrecen accesorios, muñecas tipo princesas que "vuelan" y "Ponis" luminosos a los que se los puede peinar (imagen $n^{\circ} 4$ ). Además, en los videos, los niños aparecen en una actitud mucho más activa que las niñas, quienes suelen ser representadas en una actitud más bien pasiva y sobre todo, interesadas en el embellecimiento de su persona, como "un deber ser" naturalizado del género femenino.

Otro aspecto interesante de estas publicidades, es que en los videos con juguetes "para nenas", la voz en off es siempre de femenina y suele utilizarse una música tranquila que acompaña sus palabras relativamente suaves. En cambio, en 
los videos con juguetes "para nenes" la voz en off es masculina y suele expresarse de manera fuerte y rápida mientras la música de fondo es más potente ${ }^{12}$.

Así, de acuerdo con lo observado en estos anuncios, se encontró que los medios se han convertido en instituciones más que relevantes para la reproducción ideológico-androcéntrica, operando con modelos que evocan de modo sutil elementos de violencia simbólica para con el rol de género femenino, puesto que, tal como se señala en el texto de la Ley 26.485 este tipo de violencia se da cuando "a través de patrones estereotipados, se trasmite y reproduce dominación, desigualdad y discriminación en las relaciones sociales (naturalizando la subordinación de la mujer en la sociedad) de modo recurrente, en el ámbito mediático, es decir, promovido por los medios de comunicación a través de ciertos aspectos estigmatizantes, generalmente, en detrimento de las mujeres".

\section{Así, la Violencia Mediática es:}

Publicación o difusión de mensajes e imágenes estereotipados a través de cualquier medio masivo de comunicación, que (...) discrimine, deshonre, humille atente contra la dignidad de las mujeres, (...) legitimando la desigualdad de trato o construya patrones socioculturales reproductores de la desigualdad"(Observatorio de la discriminación en radio y televisión, Publicidades sexistas y buenas prácticas, 2014).

De este modo, se sostiene que las publicidades de juguetes infantiles diferenciados, contribuyen a la naturalización de roles (actitudes, formas de ser, de sentir) estipulados según género, reproduciendo ciertos mandatos que, en el fondo, subordinan a la mujer en la sociedad y que reflejan cómo los medios de comunicación continúan reproduciendo una ideología patriarcal a pesar de la existencia (al menos en la Argentina) de un marco legal que establece lo contrario.

Tal como lo señala el documento "Plan Nacional contra la Discriminación”, la discriminación por género se ejerce en función de una "construcción simbólica socio-histórica que asigna determinados roles y atributos socio-culturales a las personas, a partir del sexo biológico y que convierte la diferencia sexual en desigualdad social, estableciendo una jerarquía en la cual todo lo masculino es valorado como superior respecto a los atributos considerados femeninos" (INADI, 2005, p.146). 
En la cotidianeidad, esto puede implicar que varones y mujeres no suelan ocupar el mismo lugar, no sean valorados de la misma manera, no tengan las mismas oportunidades, ni un trato igualitario en nuestra sociedad, relegando a las mujeres a una situación de subordinación. Los medios de comunicación de masas, a través de la publicidad trabajan simbólicamente con modelos que reproducen y ejercen de manera sutil diversos tipos de discriminación, entre los cuales se encuentra la sexista, a partir de elementos culturales y sociales aceptados y, en apariencia, "neutrales". "El androcentrismo aporta la legitimación cultural y estructural de la violencia directa y la justificación ideológica de las normas de acción para perpetuar la discriminación de las mujeres y mantener la verticalidad de las relaciones intergénero" (RadlPhillip, 2011, p. 12).

Otro ejemplo característico de productos y roles diferenciados según género lo constituye la publicidad de pañales "Huggies" del año 2014 (imagen $n^{\circ} 5, n^{\circ} 6$ $\mathrm{y}^{\circ} 7$ ), donde se propone un producto diferenciado por género, a partir de la utilización de ciertos colores y roles (rosa y celeste, princesa y campeón) pero justificando que esta distinción se debe a "una absorción frontal especialmente pensada para ellos"; y "una absorción central especialmente pensada para ellas" (imagen $\mathrm{n}^{\circ} 5$ ); es decir amparándose en un atributo biológico.

Imagen 5. Pañales con distinción según género (2013)

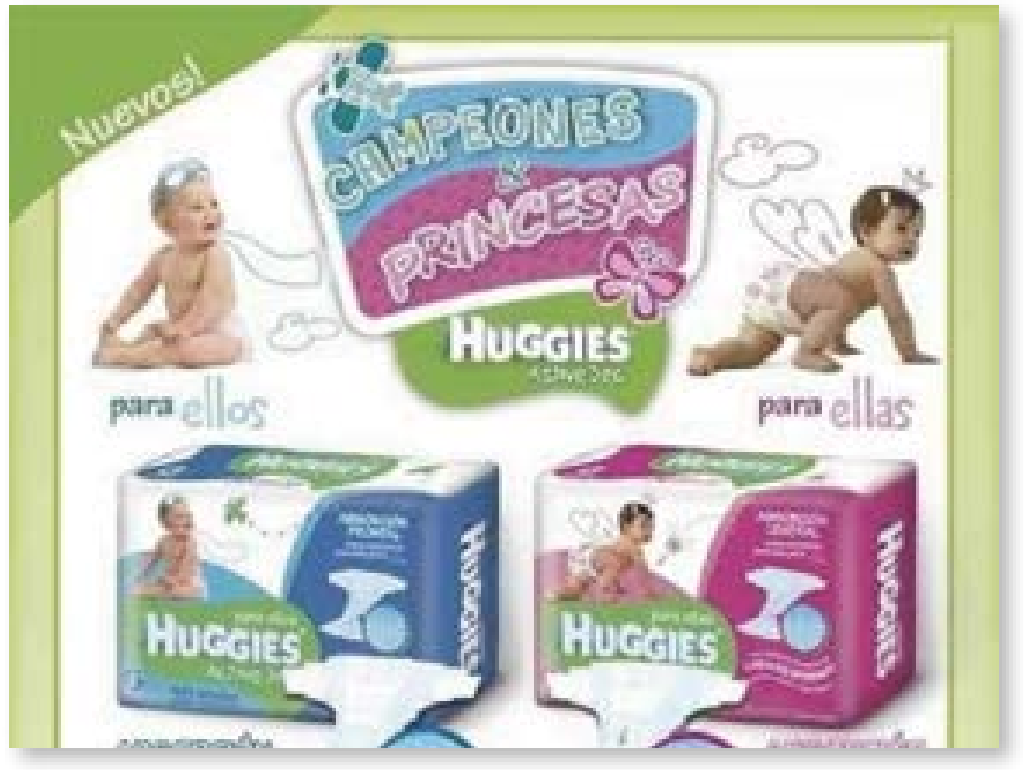

Fuente: Mercado libre. Recuperado de http://articulo.mercadolibre.com.uy/MLU433994462-panales-huggies-princesas-y-campeones--_JM 
Sin embargo, como es posible apreciar (sobre todo en las imágenes $\mathrm{N}^{\circ} 6$ y 7 ) esta estrategia de marketing se utiliza para marcar y diferenciar dos mandatos sociales estereotipados, distintos según sean niñas o niños. A partir de la configuración del "packaging", distinguiendo los paquetes según color y según un rol asignado de acuerdo con el sexo, reproducen estereotipos de género y refuerzan la división entre los sexos.

\section{Imagen 6. Pañales de color según el género (2013)}

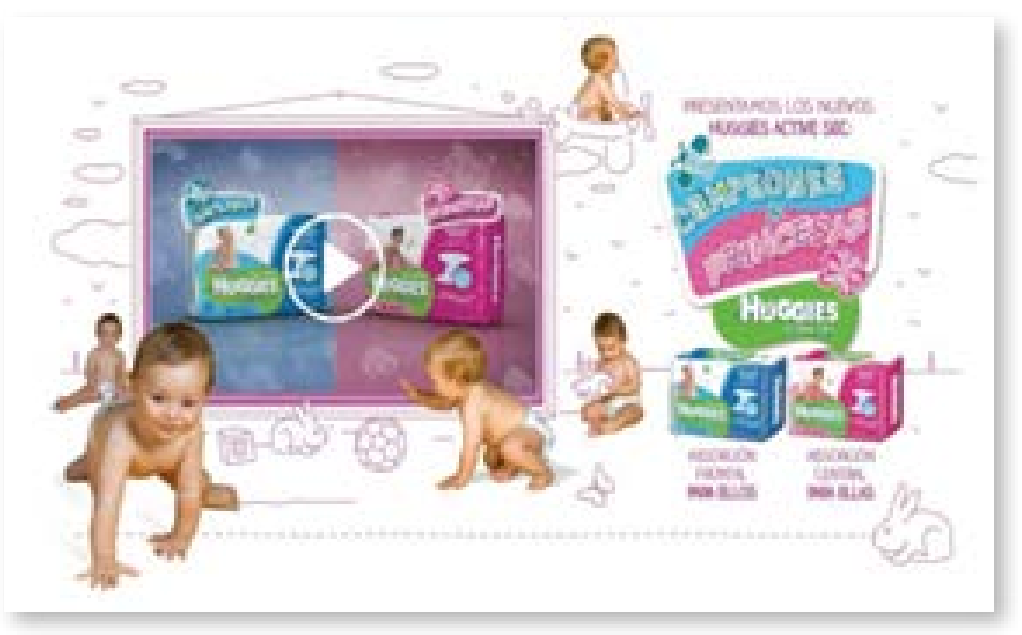

Fuente: Mercado libre. Recuperado de http://articulo.mercadolibre.com.uy/MLU433994462-panales-huggies-princesas-y-campeones--_JM

En la imagen $n^{\circ} 7$ se observa a una niña/bebé y detrás de ella el bosquejo de un castillo, con lo cual se podría interpretar que a las mujeres les correspondería ser Princesas, lugar históricamente pasivo respecto de los varones. 


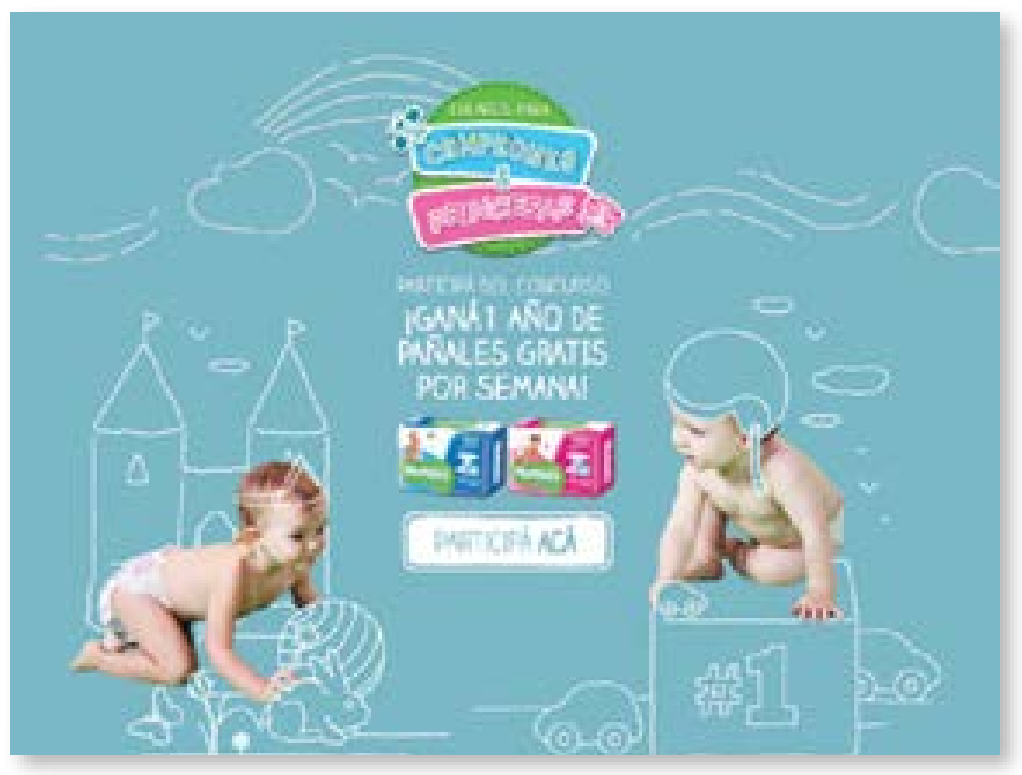

Fuente: Infokioscos. Recuperado de: http://infokioscos.com.ar/13549/promocionhuggies-cuentos-de-campeones-y-princesas.html

En cambio, según el mensaje que transmite la pauta publicitaria; a los varones les correspondería ocupar el puesto número 1, siendo este el lugar de los Campeones. Se puede ver al niño subido a una tarima que lo coloca en una posición superior al nivel de donde está la niña. De este modo, se visualiza que esta publicidad pretende representar a las nenas y los nenes a partir de una construcción de roles de género que estaría presente desde la socialización primaria de los y las infantes. 
En este contexto es posible advertir cómo los medios de comunicación contribuyen a una representación falseada de la realidad social a través de una sobre-representación del protagonismo masculino y de una sub-representación del protagonismo social femenino (RadlPhillip, 2011). En este contexto resulta adecuado traer el concepto de Fagoaga (1993) referido a la función ideológicamente regresiva de los medios, ya que da cuenta del mantenimiento de estructuras de poder, que en rol femenino es regresivo porque no llegan a ser retratadas en las funciones que realmente representan: es el caso de la tradicional representación de la mujer "Princesa" a la espera de su "Príncipe", que pone como valor principal de ellas, la paciencia y la sensibilidad o emocionalidad, mientras que a los varones los representarían fuerza y se los asocia frecuentemente con actividades deportivas, públicas y con el éxito social.

De este modo, la publicidad que promociona productos infantiles, en este caso pañales, mantendría una visión anclada en un dominio masculino, falseando, muchas veces, la propia realidad social que muestra, cada vez más, una situación muy distinta acerca del protagonismo social tanto de mujeres y varones. Así, la publicidad se remite a una división sexual del trabajo sostenida en supuestas diferencias biológicas que atribuían al hombre mayor fuerza física y a la mujer mayor capacidad emocional. No se puede afirmar que por sí solos, los medios de comunicación construyan identidades de género pero sí que como agentes de socialización ayudan a consolidarlas, puesto que son una fuente inagotable de "educación", o mejor dicho, de dispositivos de control social informal que, en muchos casos, ubican a las niñas en un papel que radica en caracterizar a la mujer como sumisa/dependiente, estableciendo, sutilmente, la suposición de un "deber ser" para todas las mujeres (y también para los hombres), según mandatos sociales fuertemente arraigados.

Habiendo dado cuenta de las formas en que las publicidades de productos infantiles reconstruyen y reproducen modelos y roles diferenciales de acuerdo con el género, es necesario enunciar otro proceso relacionado a esta primera cuestión; la reproducción y perpetuación del modelo de mujer madre, que las publicidades, como veremos a continuación, tan eficazmente consolidan y sustentan.

\section{El estereotipo de Mujer-Madre encargada del cuidado.}

En el discurso publicitario/mediático, en términos generales, la imagen masculina suele vincularse exclusivamente al ámbito laboral y público y, en contadas ocasiones, a las tareas del hogar: pues, en el ámbito mediático, ese rol, generalmente, se le atribuye a las mujeres, asociándolas, muchas veces (y casi exclusivamente), con la maternidad, insertas en el ámbito privado-doméstico 
como encargadas por excelencia del cuidado y la educación diaria de sus hijos/ as. Es por ello que no resulta sorprendente la frecuencia con que se da la representación de personajes femeninos en los comerciales que promocionan productos para el cuidado de la salud sobre todo infantil. Se ha encontrado que abundan los avisos de este tipo que estarían dirigidos sólo a mujeres, a pesar de que el producto puede ser utilizado también por varones.

En los ejemplos que a continuación se presentan, los productos "que sanan" son asociados, en la mayoría de los casos, con el rol estereotipado de la mujer en tanto madre y responsable exclusiva de la protección de los infantes y la familia en general. De esta manera, se evidenciaron numerosas campañas gráficas publicitarias que intentan atraer a los consumidores a través de discursos sexistas. Un ejemplo de ello lo constituye la marca "Vick" (de productos para resfríos y congestiones) que a través de su espacio en Facebook, "Vick Argentina"13, ha recurrido a la representación de la perpetuación de roles que históricamente se han asociado al género femenino (en este caso el de Mujer-Madre-Cuidadora). Se han seleccionado algunas publicidades del año 2012 (ver imagen $n^{\circ} 8$ ), que, si bien no refieren a productos exclusivamente para público infantil, interpelan a los adultos (generalmente a la madre) para vender el producto, estableciendo que el mismo es apropiado para ser utilizado en el cuidado de los infantes y/o la familia en general.

Imagen 8. La publicidad para niños interpela a los adultos (2014)

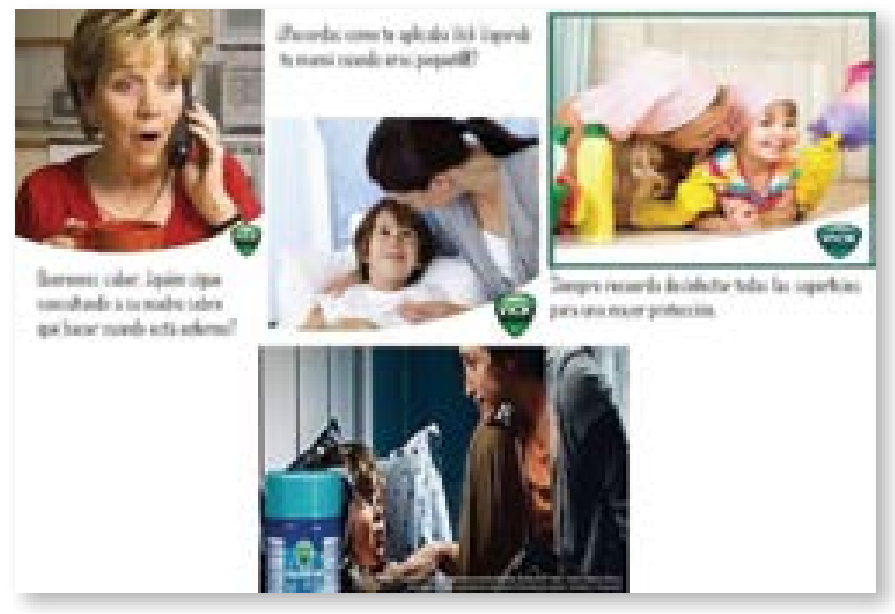

Fuente: Vick Argentina. Recuperado de https://www.facebook.com/Vick.Argentina 
No resulta casual que en las publicidades se instale la noción de que "las mujeres están destinadas al cuidado", mientras que los hombres sólo se ocupen de ello, "a veces", pues desde los avisos se suele contribuir a reproducir cierto discurso acerca de que los hombres "ayudan" a las mujeres, por ejemplo en tareas del hogar, pero "esta colaboración no cuestiona el rol protagónico que ocupan las mismas en la realización de esos quehaceres" (Publicidades sexistas, Observatorio de la discriminación en radio y televisión, 2013).

Por otro lado, en los últimos años, algunas marcas han optado por crear anuncios en los cuales se recurre a la figura del padre y se lo muestra realizando ciertos cuidados o tareas de tipo doméstico. Sin embargo, Vences (2008) sostiene que cuando aparecen en su faceta de padres, se los ubica representando una imagen de progenitor idílico y modelo a seguir por los hijos. Este puede ser el caso otra publicidad de la misma marca, pero del año 2014 (imagen $n^{\circ}$ 9), aunque no deja de constituir un avance, el hecho de que la empresa haya decidido incluir la figura masculina en publicidades gráficas de su productos, que están dirigidos sobre todo, al cuidado de los y las menores ${ }^{14}$.

\section{Imagen 9. La publicidad acude a la seguridad que transmite la figura del padre o madre (2014)}

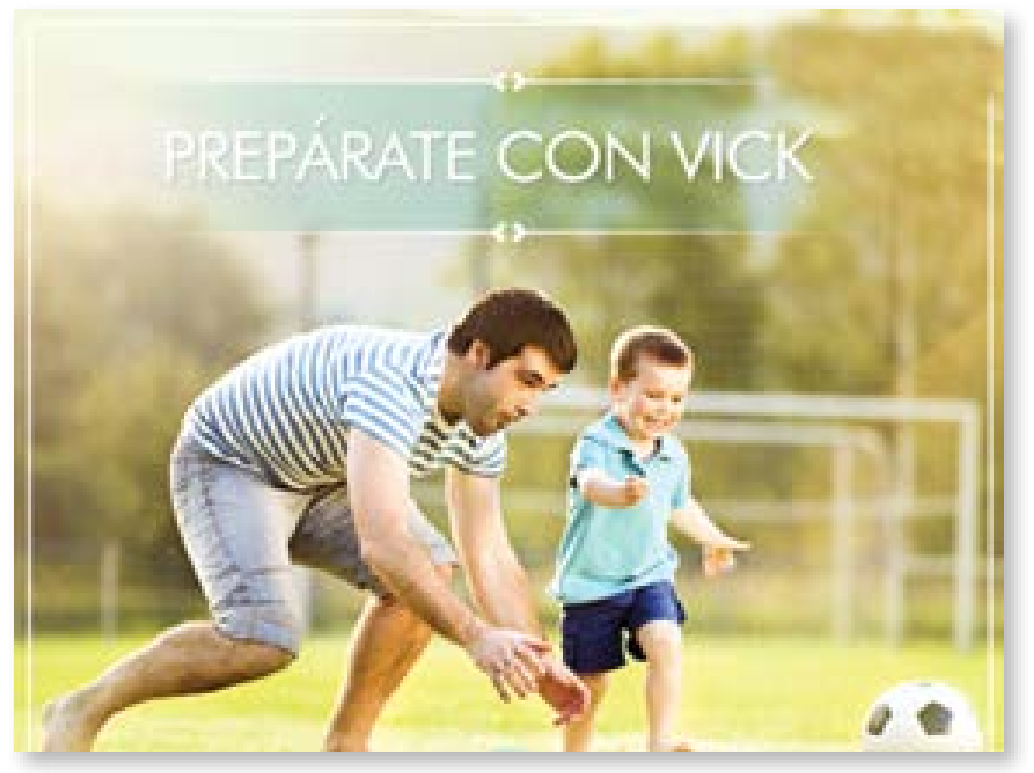

Fuente: Vick Argentina. Recuperado de https://www.facebook.com/Vick.Argentina. 
Otro ejemplo de esta situación aparece en un anuncio televisado de "Hipoglós" (marca de productos de cuidado personal, en especial de niños/as), correspondiente a una campaña del año $2011^{15}$. En el mismo se observa (imagen $\mathrm{n}^{\circ} 10$ ) cómo también interpela a la Mujer-Madre-Cuidadora; excluyendo a la figura del Padre-Cuidador. Al finalizar el anuncio publicitario, una voz de mujer señala que el producto es "recomendado por generaciones de pediatras, madres y bebes".

\section{Imagen 10. Se interpela a la Mujer-Madre} y excluye a la figura del Padre-Cuidador (2014)

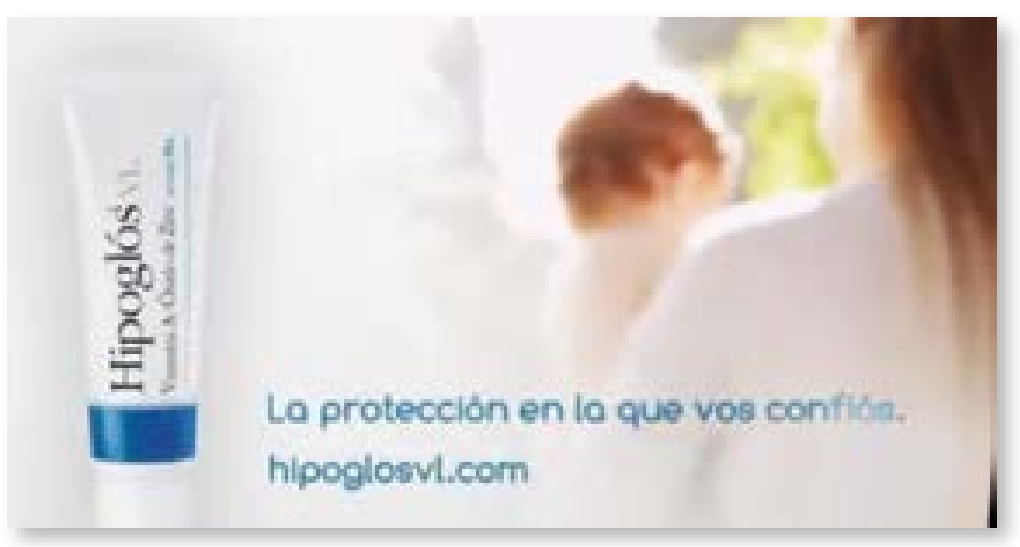

Fuente: Youtube. Recuperado de https://www.youtube.com/watch?v=RcrrYxstgWQ

La maternidad es una escena comúnmente utilizada en la publicidad: no sólo porque trasmite "ternura" sino que suele ser utilizada como un símbolo del crecimiento y evolución de los hijos/hijas y a la vez la madre funciona como referencia para el posible público comprador. El problema radica en que las publicidades de productos relacionados al cuidado (por ejemplo, del cuerpo tanto propio como ajeno), utilizan de manera preponderante la imagen de la mujer en su papel de protectora, preocupada por el cuidado de los hijos/as, y responsable central del bienestar familiar, naturalizando el rol de las mismas en la sociedad (Mujer igual Madre), pero sobre todo adjudicándole una responsabilidad no equitativa con el rol del padre.

A su vez, en aquellos casos en que aparece representando el varón/padre se suele "ridiculizar" el rol del hombre "amo de casa", pues éste es ubicado en lugares donde suele ser poco habitual su representación (Fernández, 2004), como es el 
caso del video "Hipoglós: un mensaje para Papá” en el cual, se puede observar la figura del hombre de manera humorística y heroica a la vez ${ }^{16}$ (imagen $n^{0} 11$ ).

Imagen 11. Se afianza publicidad con figura de padre humorístico, cercano (2014)

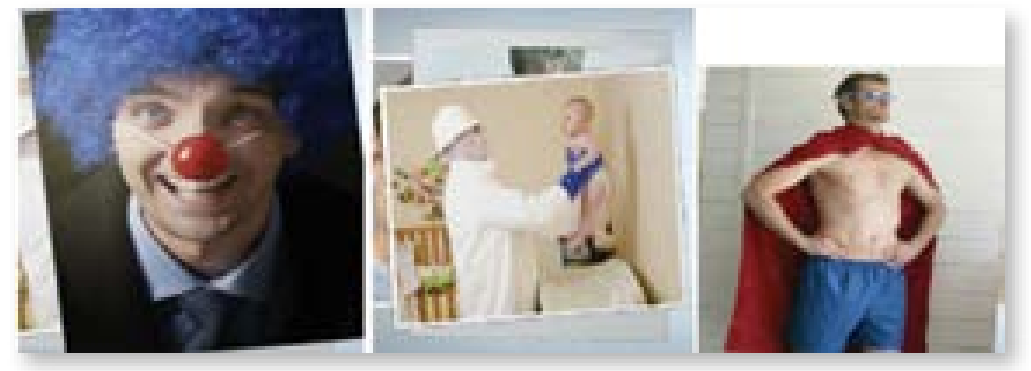

Fuente: Hiploglós. Recuperado de https://www.youtube.com/ watch? $v=E W S z G C 5 O b 5 Y$

Otra publicidad de la marca (2013) que se titula "Hipoglós - Un mensaje para Mamá” ${ }^{17}$, presenta exclusivamente imágenes de madres atendiendo al cuidado de bebés y jugando con ellos (imagen $n^{\circ} 12$ ) pero de un modo naturalizado en comparación con la publicidad para padres. Al finalizar el anuncio, se visualiza la siguiente frase "Mas de 70 años acompañándote en el cuidado de tu familia", que interpela exclusivamente a la mamá

Imagen 12. Se muestra a la Mujer-Madre que atiende y juega (2014)

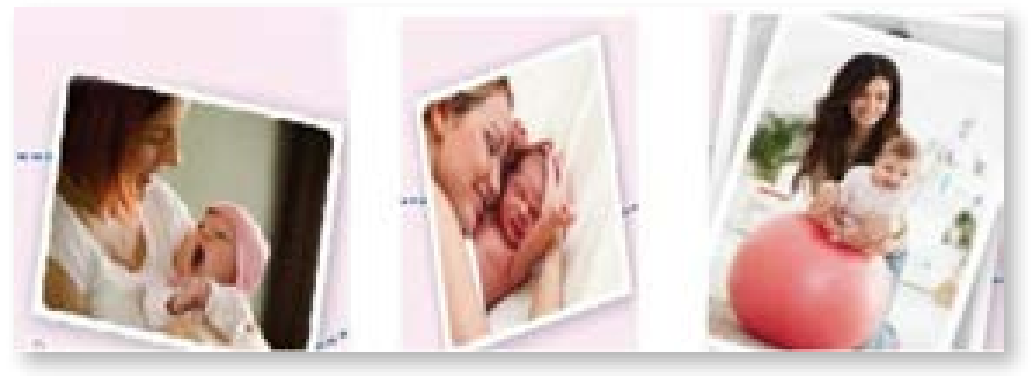

Fuente: Hiploglós. Recuperado de https://www.youtube.com/ watch? $v=y A V I q E p w D h A$

16. https://www.youtube.com/watch?v=EWSzGC5Ob5Y

17. https://www.youtube.com/watch?v=yAVIqEpwDhA 
Este tipo de referencia abunda en las publicidades con productos para el cuidado de los infantes, los destinatarios, usualmente no son los hombres; porque como afirma Fernández (2004) "su presencia se omite de tal manera que se le imprime un valor mayor al papel de la madre que al del padre” (p. 49), como si ellas tuvieran un mayor entendimiento en asuntos del cuidado en general, convirtiéndose en la figura más importante para el niño/niña. De esta manera, es la que siempre aparece a su lado, juega con él, lo cuida, lo acaricia, mima, etc., tal como se puede apreciar en esta pauta publicitaria y en otras anteriores de la misma marca ${ }^{18}$.

La publicidad de "Bagóvit" (imagen $n^{\circ} 13$, año 2012) es similar en tal sentido. A la imagen de la figura madre caminando de la mano con su bebé, le sigue la siguiente frase: "Cuida lo que más querés, con la protección más segura”.

Imagen 13. Se refuerza la figura de Mujer-Madre como protectora (2014)

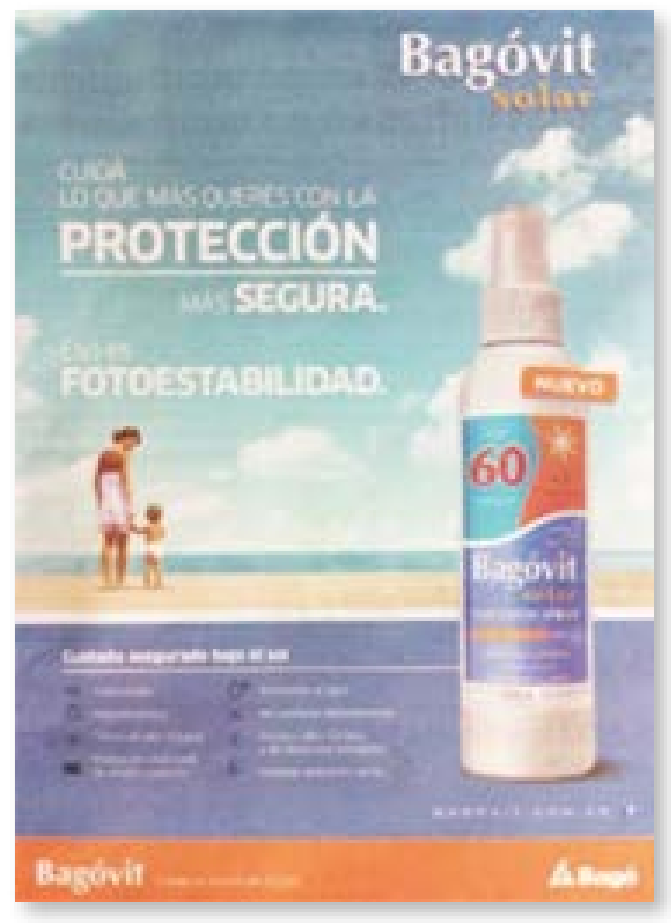

Fuente: PharmaBiz. Recuperado de http://www.pharmabiz.net/solares-bago-sacatajada/ 
Asimismo, numerosos avisos suelen relacionar a las mujeres con el ámbito doméstico. Al pretender vender productos alimenticios y del hogar en general (como los de limpieza) la mujer es la figura protagonista, en contraposición con la figura masculina que usualmente, es presentada en ambientes externos y realizando actividades de mayor status social (Furhnam, 1999).

Si bien hace muchos años la mujer se ha insertado en diversos ámbitos de los cuales permaneció excluida durante mucho tiempo y comenzó, también, a realizar numerosas actividades vedadas históricamente; en esta "revolución" de los roles femeninos, la publicidad, transmisora de mensajes y valores, no ha contribuido a representar una imagen más actual del papel de las mujeres en la sociedad, salvo en contadas ocasiones. Por el contrario, continúa contribuyendo a la reproducción de obsoletos estereotipos sexistas que relegan a las mujeres al ámbito privado, en la función (como se ha visto) de madre-cuidadora, preocupada por la salud, bienestar, alimentación de sus hijos/as.

En "su rol” de encargada de las tareas del hogar, la publicidad, suele acudir al estereotipo de la mujer cuidadora en anuncios relacionados con el sector de la alimentación (Fernández, 2004), cuestión que se observa en las publicidades de los productos alimenticios de las marcas "Luchetti" y "Granja del Sol" (imagen $\left.\mathrm{n}^{\circ} 14, \mathrm{n}^{\circ} 15, \mathrm{n}^{\circ} 16 \mathrm{y} \mathrm{n}^{\circ} 17\right)$. Si bien estos productos no son exclusivamente para infantes, las publicidades interpelan y proponen que sean consumidas (casi exclusivamente) por el público infantil-juvenil y para ello recurren a la figura de la madre que cocina para sus hijos/as.

Imagen 14. Mujer trabajadora que rivaliza con el hombre en elaboración de alimentos (2014)

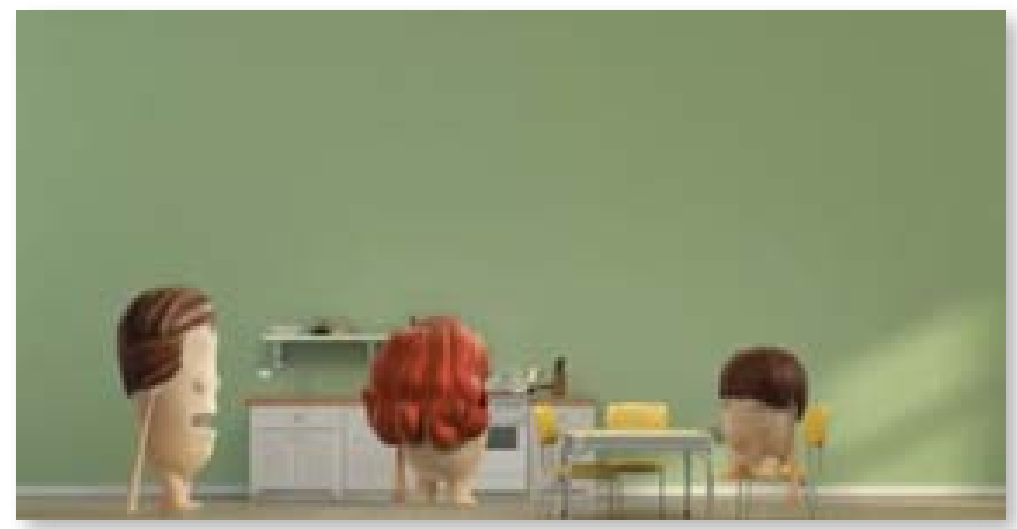

Fuente: Luchetti. Recuperado de https://www.youtube.com/ watch? $=$ vA2 $b H v 4 G t-Q$ 
En la publicidad audiovisual ${ }^{19}$ de la marca "Luchetti" del año 2012 se recurre la figura de la mujer trabajadora, pero asociada con las tareas del hogar, en claro agravio comparativo con los hombres, cuya imagen suele ser representada por los medios, como vinculada, exclusivamente, al ámbito laboral (Vences, 2008). Al avanzar el anuncio se ve la típica representación (imagen $n^{\circ} 14$ ) de la madre en la cocina preparando la comida a la familia, mientras el marido observa y el hijo espera sentado que su madre sirva los platos.

Al finalizar el anuncio (imagen $n^{\circ} 15$ ), el hijo aparece con un cartel que dice "Las milanesas de mamá son lo más". Además, el video remite a una publicidad bastante antigua en la que se reproducen roles de género al interior del hogar, donde el ámbito público es asociado al hombre y el privado a la mujer, legitimándose la división sexual del trabajo, por la cual el espacio privado se reduce a la casa, cuyas acciones se vinculan a la familia y a lo doméstico y donde las mujeres tienen un papel protagónico que no es valorado por la sociedad (INMUJERES, 2004).

\section{Imagen 15. Se distinguen ámbitos de la mujer (privado) hombre (público) (2014)}

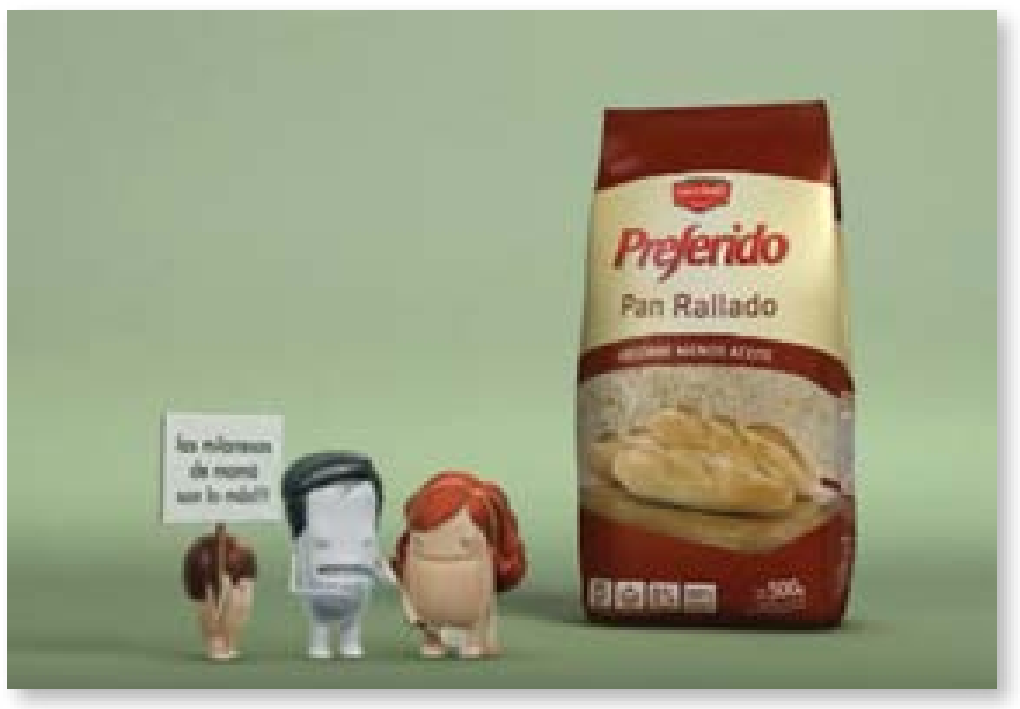

Fuente: Luchetti. Recuperado de https://www.youtube.com/ watch?v=vA2bHv4Gt-Q 
Otro ejemplo de este proceso aparece reflejado en el video de la publicidad de "Patitas Granja del Sol”20 (2012). Este comienza representando a la Mujer-Madre de un modo bastante usual para el discurso publicitario, mediante una apelación de tipo emocional, presentando al género femenino en un rol puramente afectivo. Precisamente, se observa a un niño que quiere comer "patitas"; y, para ello, convence, persuade, quizás, “engaña” a su madre para que le compre el producto mostrándose cariñoso con ella cuando lo lleva a la escuela (imagen $n^{\circ} 16$ ).

\section{Imagen 16. Se busca mostrar que el niño "engaña" para que le compren (2014)}

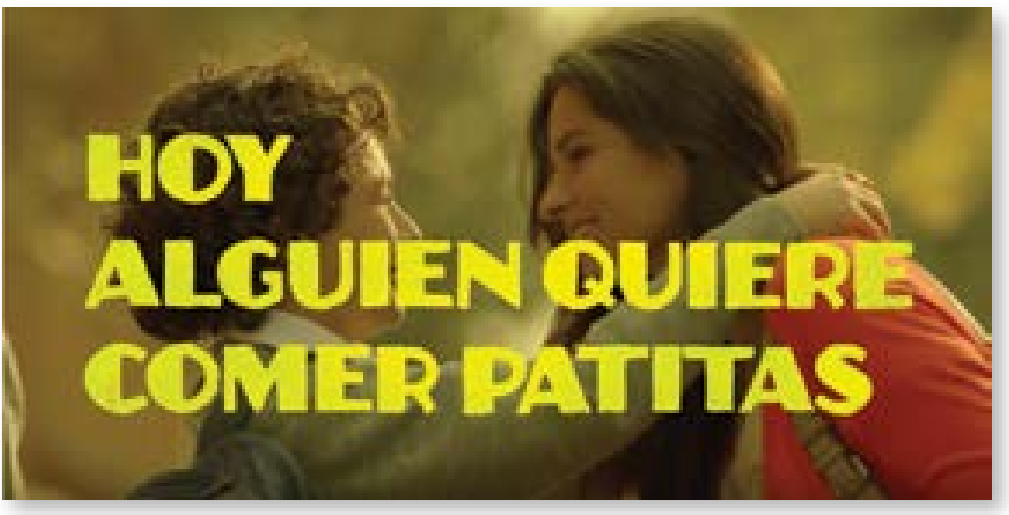

Fuente: Youtube. Recuperado de https://www.youtube.com/watch?v=-JurpAgt02Y

El género, como una construcción relacional, puede vislumbrarse en estas imágenes que nos brindan los medios que presentan estos avisos con nociones y conceptos que crean roles complementarios de los géneros presentando a la masculinidad asociada al engaño, el provecho, la ventaja, mientras que las mujeres son presentadas como débiles, indefensas y crédulas que caen en los "juegos" que ellos les arman. Al mismo tiempo se visualiza en dicha publicidad como los niños y niñas impulsados por el acoso publicitario, "manejan" a sus padres, convenciéndoles que les compren tal o cual producto, invirtiéndose así la tradicional relación de autoridad familiar.

En la siguiente y última imagen $\left(\mathrm{N}^{\circ} 17\right)$ también se presenta sólo a la Mujer (en ningún momento se ve la imagen del padre) y la muestra cocinando para sus hijos/as en el interior del hogar. 
Imagen 17. Se enfatiza papel de la Madre proveedora de alimentos (2014)

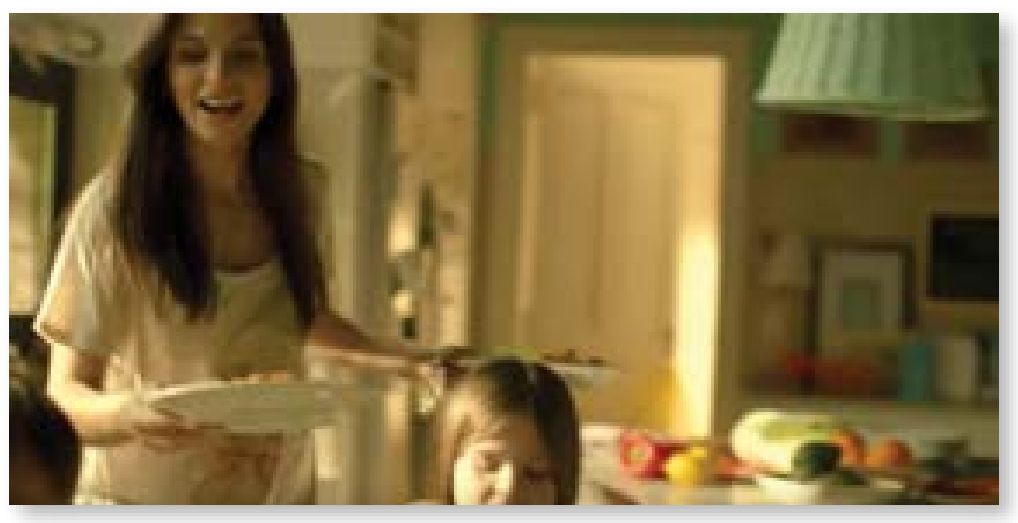

Fuente: Youtube. Recuperado de https://www.youtube.com/watch?v=-JurpAgt02Y

Además, se oye en el video una voz en off masculina que interpela directamente a la Mujer-Madre-proveedora de alimentos representada en las imágenes, diciendo: "Disfruta darles lo que más les gusta". Cuando finaliza, es una voz en off, pero esta vez de mujer, la que grita: "A comeeeeeer" (recurso utilizado por la marca de manera continua).

En este contexto se asiste a una reproducción de ciertos roles de género (comportamientos, actitudes, obligaciones y privilegios que una sociedad asigna a cada sexo y espera de él) que remiten a un modelo de mujer que suele ser representada desempeñando no sólo su papel de cuidadora-cocinera (es decir su desempeño como ama de casa que atiende a la familia) cuando se quiere vender un producto que apunta al público infantil-adolescente, sino que también recurre a un patrón de conducta que la relaciona con lo sentimental-emocional, estereotipo que suele contraponerse a la apelación de tipo racional destinada a los varones (Uribe et al., 2008).

Aquí se hace presente una vez más la división sexual del trabajo, que asigna compulsivamente el trabajo doméstico y la crianza de los hijos a la mujer, mientras que "libera" al hombre de estas tareas, posibilitando que su fuerza de trabajo sea puesta al servicio, exclusivamente del trabajo productivo. En este sentido, puede decirse que ciertos enfoques que explican la división sexual del 
trabajo por factores "innatos" tales como, la capacidad biológica de procrear o por las diferencias de aptitudes, etc., actúan naturalizando el fenómeno (Ginés, s. f.).

Precisamente, desde el discurso publicitario, a las mujeres se las somete, en ocasiones, a un tratamiento discriminatorio, mostrando, únicamente, algunos aspectos de su vida, (sobre todo con lo referente al espacio familiar, a sus tareas como madre, ama de casa, etc.) de tal modo que parece que ese es el único papel que desempeña en la sociedad, y, de este modo, se reproduce la violencia simbólica que, a partir de estereotipos, excluye las manifestaciones de carácter singular (Fernández, 2004).

Más aún, la producción diferenciada y binaria de los géneros (varón/mujer) excluye porque generaliza que toda práctica, que pertenezca "naturalmente" a un lado, no pueda ser parte de la otra y, de este modo, se legitima la asignación de roles que tradicionalmente presentan a la mujer-madre, como única realizadora de los quehaceres del hogar y a los varones rara vez representados en situaciones domésticas, a pesar de que, actualmente, existen organizaciones familiares y de pareja más igualitarias.

\section{Conclusiones}

El análisis de los estereotipos de género presentes en las publicidades de productos destinados al público infantil, constituye una expresión de la actuación de los medios de comunicación y el mercado en la construcción y reproducción de violencia simbólica hacia las mujeres. En el presente trabajo se focalizó en un actor social más, entre otros, que forma parte de la construcción de relaciones de género, buscando dar cuenta de la manera en que las personas son socializadas desde muy temprana edad de acuerdo con los patrones y mandatos hegemónicos de género, construyendo estereotipos y binarismos entre los sexos, y por ende potenciales relaciones de violencia simbólica.

Este tipo de violencia suele ejercerse de manera preponderante desde el lenguaje, ya que éste reproduce (en muchos casos) supuestos no examinados, no cuestionados, funcionales a ciertos imaginarios que se naturalizan y pueden anunciar, de manera universal, qué rige para cada caso. 
En términos de Femenías (2013) se puede afirmar que "las apelaciones históricas a las mujeres en términos de: inmadura, emocional, frígida, fregona, diosa, frívola, inconsciente, vulnerable, incapaz, quejosa, loca, etc., han tenido eficacia apelativa y performativa, (sobre todo) si los discursos sociales lo ratifican" (Femenías: 2013, pp.102-103). Así, se fijan ciertos lugares simbólicos como "verdades", que excluyen a las mujeres del ámbito público y las recluyen en el ámbito privado, relacionándolas exclusivamente con la maternidad y el cuidado en general, con las tareas domésticas, entre otros.

En línea con lo afirmado, se evidencia que detrás de publicidades que se presentan como "inocentes", "ingenuas", "naturales", se reproducen mandatos de género que asignan determinados roles y tareas diferenciadas para hombres y mujeres, generalmente de detrimento de las ultimas. El uso de ciertas imágenes en las publicidades (mamás cuidando niños, niñas jugando a realizar tareas domésticas, niños manejando autos o realizando juegos violentos, por ejemplo) prescriben una serie de prácticas y roles, cuyos efectos se movilizan por el campo de lo social y cultural, generando luchas e imposiciones entre quienes se ajusten a la norma y quiénes no. Según Butler (2001), la repetición de la norma supone un acto de sujeción y un acto de violencia sobre el cuerpo. Pero esa interpelación de la norma no es un acto unidireccional, por el contrario, implica una relación más compleja, que involucra una presencia activa del sujeto, puesto que "la norma me usa precisamente en la medida en que la uso" (Butler, 2005, p. 55). De esta manera, se puede concebir a las publicidades en tanto reproductoras de la estructura heterosexual dominante, como también al público adulto al que interpelan, que participa, a su vez, de esa reproducción (voluntaria o no).

Los diversos juguetes y productos infantiles ejemplificados aquí son anunciados según la diferencia de género, construyendo a partir de la pauta gráfica y audiovisual, una identidad femenina y masculina con características estereotípicas específicas. La consolidación de estos estereotipos advierte los ejercicios de poder y violencia que determinarían el lugar que deberían ocupar en la sociedad los niños y las niñas, como futuros adultos, en perjuicio de estas últimas.

Desde la perspectiva de Bourdieu, la fuerza del orden masculino se descubre en el hecho de que prescinde de cualquier justificación. La visión androcéntrica (mirada masculina en el centro del mundo) se impone como neutra y sin que sea necesario enunciar discursos capaces de legitimarla. El orden social, funciona así, como una inmensa máquina simbólica, que tiende a ratificar la dominación masculina en la que se apoya la división sexual del trabajo, la estructura del 
espacio (ámbito público-hombre, ámbito doméstico-mujer) y la estructura del tiempo. En otras palabras, el autor explica que la división entre los sexos parece estar como "en el orden de las cosas", señalando con esto que lo establecido como "normal, natural" se extiende hasta el punto de ser inevitable, afirmando que la fuerza androcéntrica "legitima una relación de dominación, inscribiéndola en una naturaleza biológica que es en sí misma una construcción social naturalizada” (Bourdieu, 2000, p.37).

Es así que, para las niñas se plantea una preparación para el mundo doméstico, el rol de amas de casa (buena madre, buena esposa), de socializadoras del mundo afectivo, o como objeto de belleza perfecta, incluso sumergidas dentro de un mundo irreal, de princesas. En cambio para los varones el ideal planteado se basa en el acceso exclusivo a la tecnología, velocidad, fuerza, incluso la violencia. A partir del registro de publicidades de productos para el consumo de infantes, se hace notoria la existencia de dos mundos muy diferentes (y que se presentan como excluyentes), uno para niños y otro para niñas que suponen diversos roles que van a desempeñar como adulto, mujer o varón, en sociedad.

Los medios de comunicación, al constituirse en un rol preponderante en las socializaciones primarias de niños y niñas, reproducen la valoración de diversos roles según sea hombre o mujer. Pero también pueden ofrecer (y eso se espera) nuevos modelos de relación entre géneros, ya que la publicidad en general, podría abandonar la función ideológicamente regresiva (Fagoaga, 1993) que detenta, puesto que, como se ha señalado, los roles de hombres y mujeres continúan cambiando, alejándose de la representación de "hombre dominante" y "mujer madre y ama de casa". Este cambio puede trasladarse al ámbito de los niños y niñas, permitiéndoles interaccionar con distintos juguetes, sin distinción de sexos, aunque, será doblemente costoso si la publicidad no refleja estos cambios, ya que los medios en general, detentan un rol de poder en la sociedad actual.

En lo referido las legislaciones y entes de control, la legislación de nuestro país resulta adecuada, ya que sentó las bases de lo que significa violencia hacia las mujeres y definió diversos tipos y ámbitos de ejercicio de la misma. Sin embargo, queda un largo camino para un efectivo cumplimiento y sanción, para la total erradicación de la violencia hacia las mujeres. En cuanto al Observatorio de Medios, como ente regulador de los contenidos televisivos, su labor es elemental en tanto controla y regula las publicidades sexistas. Pero a su vez, resulta necesario que dicho ente comience a prestar mayor atención a los anuncios dirigidos al público infantil, ya que por lo general los niños y niñas quedan más 
expuestos y vulnerables frente al masivo ataque de las publicidades. Y a su vez, se ven tempranamente influenciados y modelados por los estereotipos de género.

Analizar la publicidad infantil y dar cuenta de su recurrente discurso legitimador de la desigualdad de género, permite (o permitirá) como primer paso desarrollar una mirada crítica frente a la problemática y establecer la necesidad de que todo comunicador/a ejerza una postura comprometida, en pos de subvertir y modificar los actuales modelos de ser varón y mujer, ser niño y niña que se presentan y reproducen.

\section{Referencias}

Bourdieu, P. (2000). La dominación masculina. Barcelona, España: Anagrama.

Butler, J. (2001). El género en disputa. El feminismo y la subversión de la identidad.

Buenos Aires, Argentina: Paidós.

Butler, J. (2005). Dar cuenta de sí mismo. Violencia ética y responsabilidad. Buenos Aires, Argentina: Amorrortu.

DGCyE (2010). Diseño curricular Escuela Secundaria $5^{\circ}$ Año. Buenos Aires, Argentina.

Ditoys Argentina (s. f.) Recuperado de http://www.ditoys.com.ar/ y http:// www.ditoys.com.ar/videos.html

Fagoaga, C. (1993). La violencia en los medios de comunicación. Maltrato a la pareja y agresión sexuada en Anuario de Hojas de Warmi. Revista de investigación para el feminismo, la cooperación y la solidaridad con América Latina, (5), 40-45. Universitat de Barcelona, España.

Femenías, M. L. (2013). Violencias Cotidianas. Rosario, Argentina: Ediciones prehistoria.

Furham, A. y Mak, T. (1999). Sex-role stereotyping in televisioncommercials. AReview and Comparison of FourteenStudies Done on Five Continents over 25 YearsenSex Roles, (41), 413-437. Springer, Estados Unidos. 
Ginés, M. (s. f.) División sexual del trabajo. Recuperado de http:// agendadelasmujeres.com.ar/notadesplegada.php?id=50

Hernandez-Sampieri, R; Fernandez, C; Baptista, P. (2007). Metodología de la Investigación. México: Editorial Mc Graw Hill.

Hipoglós Argentina (s. f). Recuperado de https://www.facebook.com/ HipoglosArgentina

INADI (2005). Hacia un Plan Nacional contra la Discriminación La discriminación en Argentina. Diagnóstico y propuestas. Buenos Aires, Argentina: Ministerio de Justicia, Seguridad y Derechos Humanos, Instituto Nacional contra la Discriminación.

INMUJERES (2004). El ABC de género en la administración pública. México: Instituto Nacional de las Mujeres/Programa de las Naciones Unidas para el Desarrollo (PNUD).

Lubertino, M. (2013). Huevos kínder celeste para niños, rosa para niñas y ahora... verdes. Recuperado de http://www.merca20.com/huevos-kinder-celestepara-ninos-rosa-para-ninas-y-ahora-verdes

Perez-Ugena, A., Martínez, E. y Martínez, Á. (2009).Informe sobre la Publicidad de Juguetes de la Campaña Navideña emitida en Televisión durante las Navidades. Universidad Rey Juan Carlos de Madrid, España.

RadlPhillip, R. (2011). Medios de comunicación y violencia contra las mujeres. Elementos de violencia simbólica en el medio televisivo, en Revista Latina de Sociología, $\mathrm{n}^{\circ}$ 1, pp. 156-181. Universidade da Coruña, España.

Scott, J. (1990). El género: una categoría útil para el análisis histórico. En Amelang, L. y Nash, M. (Comp.). Historia y género: las mujeres en la Europa moderna y contemporánea. Valencia, España: Alfons el Magnánim.

Observatorio de la Discriminación en radio y televisión (2013). Publicidades sexistas. Argentina. Recuperado de http://www.obserdiscriminacion.gob. ar/?p=1949\#more-1949 
Observatorio de la Discriminación en radio y televisión (2014) Publicidades sexistas y buenas prácticas. Argentina. Recuperado de http://www. obserdiscriminacion.gob.ar/?p=2584\#more-2584

Uribe R., Manzur, E. Hidalgo, P. y Fernández, R. (2008). Estereotipos de género en la publicidad: un análisis de contenido de las revistas chilenas en Academia. Revista Latinoamericana de Administración, (41), 1-18. Consejo Latinoamericano de Escuelas de Administración Organismo Internacional. Bogotá, Colombia.

Vences, N. (2008). Publicidades, roles sociales y género. Grupo de investigación FONTA. Universidad Complutense de Madrid, España.

Vick Argentina (s. f.). Recuperado de https://www.facebook.com/Vick.Argentina 